It is needless to say that no spectrum was observed. These facts appear to be utterly irreconcilable with the conclusion drawn by Messrs, Young and Forbes.

Schluchsee, Prussia, August 28

Albert A. Michelson

\section{Salmon in Preserved Rivers}

HAVING resided for some time lately near one of our salmon rivers which is at present preserved by a club, I have at different times had conversations with men who knew it before its socalled preservation. They all say that when they were allowed to fish when and how they pleased, the supply of fish was much better in regard both to size and quantity. They account for it in the following manner:-Firstly, when the river was free, the people living near used to make spawning-beds for the fish, by placing large stones across the river and throwing gravel where deficient, and where gravel was naturally they used to loosen it with forks and remove the large stones. Secondly, they used to watch the fish at spawnin time, and catch and kill all very large fish, say about 16 to $301 \mathrm{~s}$. weight, after they had partially or wholly finished spawning, as they say the large fish destroy the salmon fry. Neither this nor the formation of spawning-beds is done at present. Would the above reasons account for the diminution in the size and number of salmon caught in our rivers? The diminution, in the river I speak of, cannot be accounted for by pollution, as the number of hou:es near enough to send their drainage into the river is too small to affect it, and as the river has a very quick fall and rocky bed, it is subject to such very rapid rises and falls in quantity of water that wotld prevent any settlement of noxious seciiment. F. C. S.

\section{New Seismometer}

IN NATURE, vol. xxiv. $p$. II 3 , the re is a notice of a new seis mometer which has several advantages claimed for it. Might I suggest what seems an obvious and important improvement? As a rule pendulums cannot record vertical or oblique motions, and yet these are often the most necessary and valuable to record. I. To do this, and yet as easily allow of lateral registration, I would say, support a heavy (leaden) ball of some Ioolbs. by a 30 or 40 feet spiral or rubber spring of suitable stren th. It will be found that a very con iderable amount of vertical play can take place, especially vertical effort, ere the ball can be affected, and that lateral play of the support will produce very little effect indeed, unless, as is most unlikely, the motion is prolonged and is continuous in one direction. 2. Around the sphere, and at a very short distance from its surface, radial rods actuated like the key-plugs of a cornet are supported, say at every $30^{\circ}$ all over the surface, contact with any one of which will electrieally record time, and the pencil attached to the plunger record distance of stroke on revolving paper attached to plunger-tube.

Asam, July 6 S. E. PEAL

\section{THE BRITISH ASSOCIATION}

$T^{H}$ $\mathrm{E}$ actual number of persons who attended the York Meeting of the British Association, as announced at the last meeting of the General Committee, was 2556 ; divided between 272 old life-members, 27 new life-members, 3 I 2 old annual members, 175 new annual members, 1232 associates, 5 I 4 ladies, and 24 foreigners. The seven previous occasions on which this number has been exceeded were :- Newcastle-on-Tyne, I863 (3335); Manchester, I86I (3I38); Liverpool, I870 (2878); Bath, I 864 (2802); Glasgow, 1876 (2774); Dublin, i878 (2578); Aberdeen, $1859(2564)$. The number fell below rooo at Cambridge, Plymouth, Southampton, Ipswich, Hull, and Swansea. I280l. were paid out by the Council for scientific purposes after the last meeting, a larger sum than on any occasion since 1873 ; while between 1873 and I86r that sum was always exceeded, and at Norwich, in 1868, it amounted to 1940 l.

The following foreigners were present at the meeting:-Professrs Barker of Pennsylvania; Bergeron, Paris ; Bojanowski ; Carbonnelle, Brussels ; Chemin, Paris; Craig, Johns Hopkins University, U.S. ; Dohrn, Naples; Eads, St. Louis, U.S. ; Gariel, Paris ; Dr. Asa
Gray, Harvard University ; Halphen, Paris ; Dr. Edwin Hall, Baltimore, U.S. ; Hubrecht, Leyden; Prof. W. W. Jahnson, Annapolis, U.S.; Prof. O. C. Marsh, Yale College; Moser, Berlin; Prof. H. A. Rowland, Baltimore ; Stephanos, Paris ; Sturm, Münster, Westphalia Prof. H. M. Whitney, Beloit College, Wisconsin, U.S.A.

We ought to have stated in our report of the doings of the Association in our last number, that Prof. Huxley's lecture on Palæontology, which we gave in the same number, was delivered on the evening of Friday the gth.

Nearly 350 papers or reports were read before the several sections. Of these the Physical and Mathematical Section received 89 ; the Chemical Section 49 ; Geology 59; Biology 79; Geography 16; Economic Science and Statistics 26; and Mechanical Science 29. Of the papers in Sestion A 23 related to Electricity; 21 were Mathematical; Optics claimed I2; Meteorology I1 ; Astronomy and Physical Geogriphy 12; Heat 5; and miscellaneous physical subjects 5 . Of course prominent subjects of interest were electric lighting, electric measurements, and Faure's cells. Such subjects were tho. roughly ventilated by discussions both in Section and Committee, and more intimately during the thousand and one opportunities for interchange of ideas which occurred in the afternoon and evening. Again, the storage of energy, the nature of meteoric dust, the existence of intra-Mercurial planets, the lunar disturbance of gravity, the nature of colours, and the contact theory were each severally discussed. Among the 49 Chemical papers several theoretical matters were introducedspecially the atomic theory, chemical nomenclature, vapour densities, molecular weights, Mendeleeff's law, and molecular attraction; processes of analysis and technical operations were described, and new experiments were explained. Of course a good deal of the geological work bore reference to Yorkshire, especially to the evidences of glacial action which it presents. The geological papers were of a very general and interesting character, and embraced every branch of the subject, from the vulcanology of Japan to the minerals found at Laurium, and from the Cheshire salt beds to the evolution of the Plesiosaurus. Section D furnished a larger number of papers than any other Section except $A$, but we must bear in mind that it really consists of three sub-sections, devoted respectively to Zoology and Botany, Anatomy and Physiology, and to Anthropology. The latter subject bas developed extraordinarily, more than half the papers con. tributed to the Section were read before this Sub-Section. The report of the Anthropometric Committee, which evoked a good deal of discussion, was read in the Section of Economic Science and Statistics. In this section Mr. Grant Duff delivered a very able address, which was warmly received. A tendency to introduce matter which has a political bearing and which may be discussed from a political standpoint is sometimes apparent in this section, and should be carefully guarded against by the Committee. The Mechanical Section furnished some important reports on patent laws, wind pressure, tides in the English Channel, and the steering of screw steamers. Here also were papers on the different forms of electric lamp, the electrical transmission of force, and the illumination of lighthouses.

Thus it will be seen that all the prominent subjects of science have received their share of attention, and at the hands of one or other of the sections have been either expanded or discussed. The interchange of ideas has been incessantly going on, and many men bave become acquainted who might otherwise have remained unknown to each other for years. Same 500 scientific men have been gathered together from various parts of the British Islands; and some 2000 persons have been brought face to face with the burning scientific questions of the day, and have had new interests awakened, or old knowledge resuscitated. There can be little doubt as to the 